Prepared in cooperation with the New Hampshire Geological Survey

\title{
Temperature Logging of Groundwater in Bedrock Wells for Geothermal Gradient Characterization in New Hampshire, 2012
}

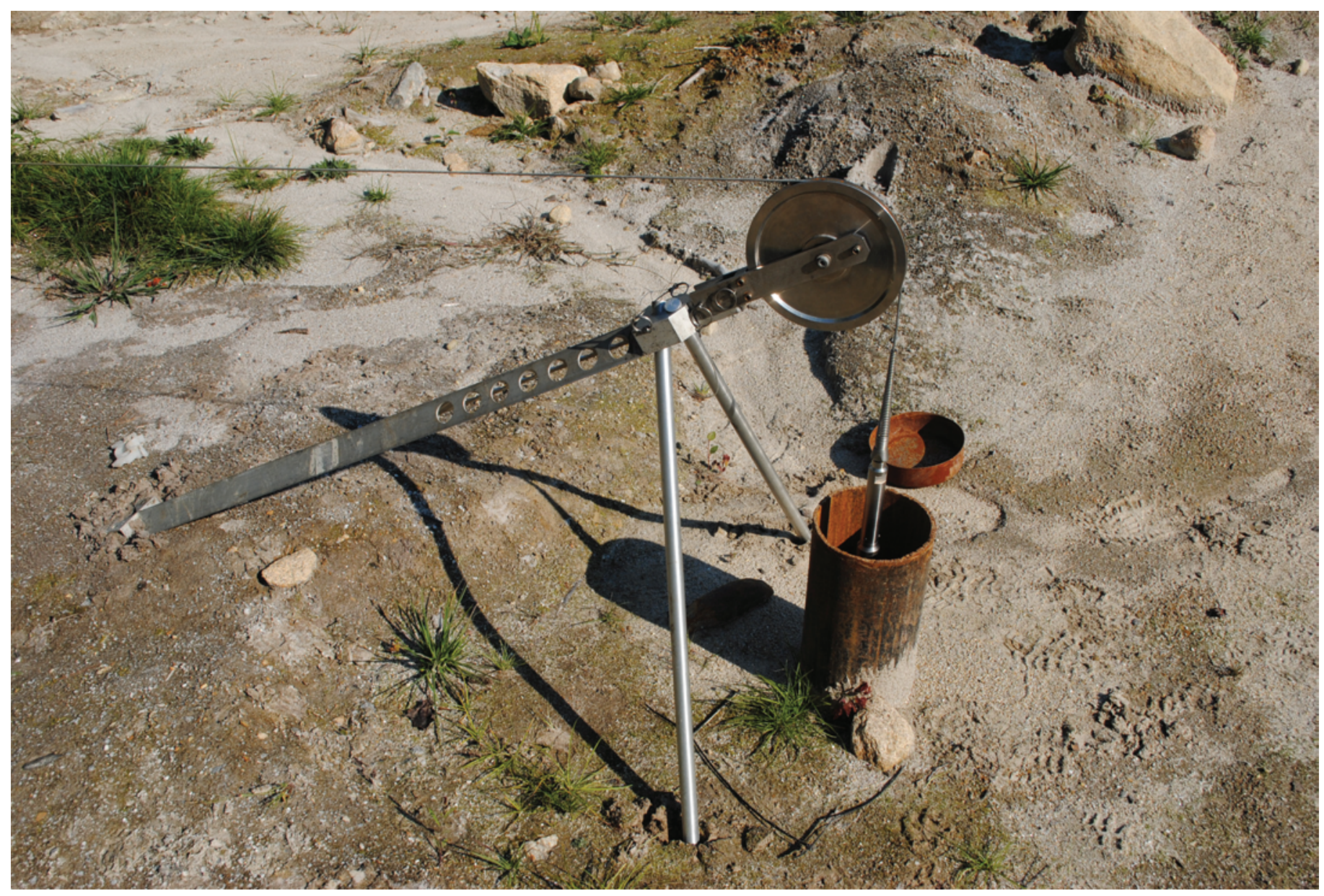

Data Series 728 
Cover. Borehole logging cable and well at Mason, New Hampshire. U.S. Geological Survey photograph. 


\section{Temperature Logging of Groundwater in Bedrock Wells for Geothermal Gradient Characterization in New Hampshire, 2012}

By James R. Degnan, Gregory Barker, Neil Olson, and Leland Wilder

Prepared in cooperation with the New Hampshire Geological Survey

Data Series 728 


\section{U.S. Department of the Interior \\ KEN SALAZAR, Secretary \\ U.S. Geological Survey \\ Marcia K. McNutt, Director}

\section{U.S. Geological Survey, Reston, Virginia: 2012}

For more information on the USGS - the Federal source for science about the Earth, its natural and living resources, natural hazards, and the environment, visit http://www.usgs.gov or call 1-888-ASK-USGS.

For an overview of USGS information products, including maps, imagery, and publications, visit http://www.usgs.gov/pubprod

To order this and other USGS information products, visit http://store.usgs.gov

Any use of trade, firm, or product names is for descriptive purposes only and does not imply endorsement by the U.S. Government.

Although this information product, for the most part, is in the public domain, it also may contain copyrighted materials as noted in the text. Permission to reproduce copyrighted items must be secured from the copyright owner.

Suggested citation:

Degnan, J.R., Barker, Gregory, Olson, Neil, and Wilder, Leland, 2012, Temperature logging of groundwater in bedrock wells for geothermal gradient characterization in New Hampshire, 2012: U.S. Geological Survey Data Series 728,

19 p., at http://pubs.usgs.gov/ds/728/. 


\section{Acknowledgements}

The authors would like to thank all who have assisted with and supported this project. Advice from Carole Johnson and Alton Anderson of the U.S. Geological Survey (USGS) helped in the understanding of logging results and data processing. Equipment and technical advice provided by Michael Wacker of the USGS made high-quality data collection possible.

Reviews of this report were done by Tom Mack, Mike Brayton, Rich Moore, and Anna Glover. Technical advice from Paul Staples of Mount Sopris Instruments was helpful for temperature calibration. Kelsey Regan of the USGS provided assistance with logging and data management. Permission and support from private land owners who allowed access to their wells made data collection possible. 
THIS PAGE INTENTIONALLY LEFT BLANK 


\section{Contents}

Acknowledgements.................................................................................................................ii

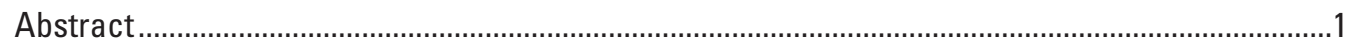

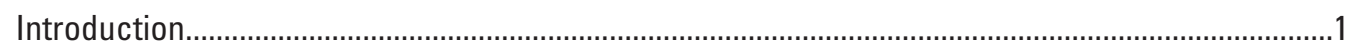

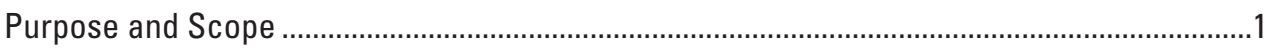

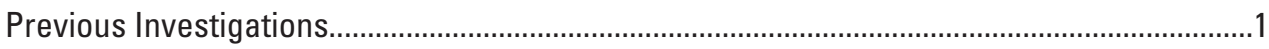

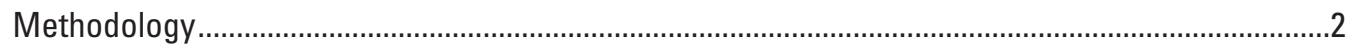

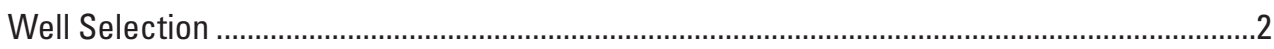

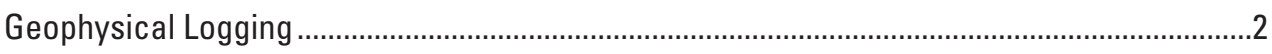

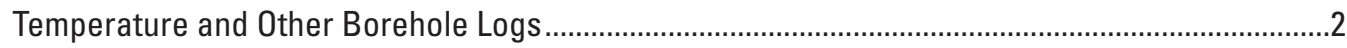

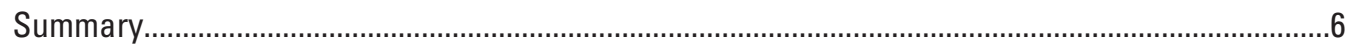

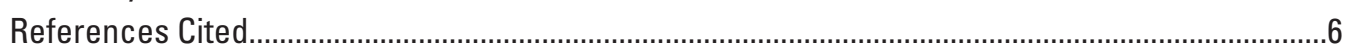

\section{Figures}

1. Map showing locations of bedrock wells logged in New Hampshire in 2012 for geothermal gradient characterization ............................................................................

2. Temperature and gamma geophysical logs from bedrock well AMW 462 in Amherst, New Hampshire, 2012 ….............................................................................10

3. Temperature and gamma geophysical logs from bedrock well BIW 1622 in

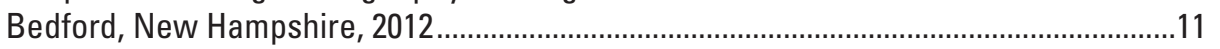

4. Temperature and gamma geophysical logs from bedrock well B4W 221 in Brookline, New Hampshire, 2012 ………………………...........................................12

5. Temperature and gamma geophysical logs from bedrock well B4W 571 in Brookline, New Hampshire, 2012 ............................................................................13

6. Temperature and gamma geophysical logs from bedrock well B4W 422 in

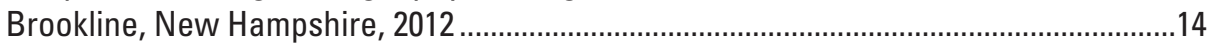

7. Temperature geophysical log from bedrock well CWW 245 in Conway, New Hampshire, 2012.

8. Temperature geophysical log from bedrock well MGW 86 in Mason, New Hampshire, 2012.

9. Temperature and conductance geophysical logs from bedrock well MGW 87 in Mason, New Hampshire, 2012 ......................................................................................

10. Temperature, conductance, and gamma geophysical logs from bedrock well OXW 117 in Ossipee, New Hampshire, 2012

11. Temperature and gamma geophysical logs from bedrock well WNW 120 in Wilton, New Hampshire, 2012.

\section{Tables}

1. Information for bedrock wells used for temperature logging of groundwater for geothermal gradient characterization in New Hampshire, in 2012..................................

2. Summary of depth, temperature, and gamma properties of wells.....................................5 


\section{Conversion Factors and Datum}

Inch/Pound to SI

\begin{tabular}{|c|c|c|}
\hline Multiply & By & To obtain \\
\hline \multicolumn{3}{|c|}{ Length } \\
\hline inch (in.) & 2.54 & centimeter $(\mathrm{cm})$ \\
\hline foot $(\mathrm{ft})$ & 0.3048 & meter $(\mathrm{m})$ \\
\hline mile (mi) & 1.609 & kilometer $(\mathrm{km})$ \\
\hline
\end{tabular}

Temperature in degrees Celsius $\left({ }^{\circ} \mathrm{C}\right)$ may be converted to degrees Fahrenheit $\left({ }^{\circ} \mathrm{F}\right)$ as follows:

$$
{ }^{\circ} \mathrm{F}=\left(1.8 x^{\circ} \mathrm{C}\right)+32
$$

Temperature in degrees Fahrenheit $\left({ }^{\circ} \mathrm{F}\right)$ may be converted to degrees Celsius $\left({ }^{\circ} \mathrm{C}\right)$ as follows:

$$
{ }^{\circ} \mathrm{C}=\left({ }^{\circ} \mathrm{F}-32\right) / 1.8
$$

Vertical coordinate information is referenced to the North American Vertical Datum of 1988 (NAVD 88).

Horizontal coordinate information is referenced to the North American Datum of 1983 (NAD 83). Specific conductance is given in microsiemens per centimeter at 25 degrees Celsius $(\mu \mathrm{S} / \mathrm{cm}$ at $25^{\circ} \mathrm{C}$. 


\title{
Temperature Logging of Groundwater in Bedrock Wells for Geothermal Gradient Characterization in New Hampshire, 2012
}

\author{
By James Degnan, ${ }^{1}$ Gregory Barker, ${ }^{2}$ Neil Olson, ${ }^{2}$ and Leland Wilder ${ }^{2}$
}

\begin{abstract}
The U.S. Geological Survey, in cooperation with the New Hampshire Geological Survey, measured the fluid temperature of groundwater in deep bedrock wells in the State of New Hampshire in order to characterize geothermal gradients in bedrock. All wells selected for the study had low water yields, which correspond to low groundwater flow from fractures. This reduced the potential for flow-induced temperature changes that would mask the natural geothermal gradient in the bedrock. All the wells included in this study were privately owned, and permission to use the wells was obtained from homeowners before logging.

Maximum groundwater temperatures at the bottom of the logs were between 11.7 and 17.3 degrees Celsius. Geothermal gradients were generally higher than typically reported for other water wells in the United States. Some of the high gradients were associated with high natural gamma emissions. Groundwater flow was discernible in 5 of the 10 wells studied but only obscured the portion of the geothermal gradient signal where groundwater actually flowed through the well. Temperature gradients varied by mapped bedrock type but can also vary by differences in mineralogy or rock type within the wells.
\end{abstract}

\section{Introduction}

Information collected from groundwater temperature logs can be used to assess the potential of geologic formations for development of geothermal energy. The temperature of groundwater within wells reflects the temperature of the surrounding geologic formations, in the absence of significant groundwater flow. Geothermal gradients from various rock

\footnotetext{
${ }^{1}$ U.S. Geological Survey.

${ }^{2}$ New Hampshire Geological Survey.
}

units measured in mines and drill holes around the world range from 0.46 to 2.29 degrees Celsius $\left({ }^{\circ} \mathrm{C}\right)$ per 100 feet (ft) of depth (Skinner and Porter, 1992). The typical range of geothermal gradients observed in groundwater wells is 0.47 to $0.6^{\circ} \mathrm{C}$ per $100 \mathrm{ft}$ (Keys, 1990), which is the range that was expected to be found in this study.

\section{Purpose and Scope}

The New Hampshire Geological Survey (NHGS) is interested in the potential for developing geothermal energy in the State. The purpose of this report is to present data regarding geothermal gradients reflected in fluid temperature of groundwater in crystalline bedrock wells in the State of New Hampshire. The information in this report can help decisionmakers to evaluate the geothermal potential of the bedrock in New Hampshire. For this study, wells were logged to determine temperature, and the data collected will become part of a national inventory of data used to evaluate geothermal potential across the United States. Temperature and gamma log data in the $\log$ ASCII standard format are part of this report.

\section{Previous Investigations}

There is a long history of efforts to study the geothermal properties of rocks in New Hampshire. Geothermal gradients within the Earth's crust are driven by the conduction of heat from the core that travels with convection currents through the mantle (Skinner and Porter, 1992). Variations in geothermal gradients are attributable to the location of the convention cells, crustal thickness, rock type, and heat production by the decay of radioactive minerals. Birch and others (1968) reported uncorrected geothermal gradients between 0.55 and $0.67^{\circ} \mathrm{C}$ per $100 \mathrm{ft}$ for sites in central New Hampshire.

Previous geothermal studies in New Hampshire, focusing largely on the Conway granite in the White Mountains of New Hampshire, were summarized by Wilder (2003). High heat production in plutonic bedrock in New Hampshire is associated with the decay of radioactive minerals, which 
was quantified by Billings and Keevil (1945). Hoag and Stewart (1977) provide a detailed lithologic and geophysical description of the geothermal test hole in Redstone (a village in Conway, New Hampshire), including a temperature log. Caruso and Simmons (1985) investigated the distribution of uranium in the Redstone geothermal test hole core. Uranium is found within minerals and microfractures that were emplaced and formed during and likely after crystallization of the granite found in the Redstone test hole. Redistribution of uranium from hydrothermal fluid circulation after crystallization can, in part, account for the high concentrations.

\section{Methodology}

Ten wells were selected for temperature logging. Additional fluid and physical borehole properties, such as fluid conductance and natural gamma radiation emissions, were collected at selected wells. Well construction data were entered into the U.S. Geological Survey (USGS) groundwater site inventory database. Log data are stored and archived in log ASCII standard format and are available as part of this report.

\section{Well Selection}

The selection of wells was made by the NHGS based on depth, bedrock type, accessibility, lack of pumps and plumbing in the well, and low potential for intraborehole flow (low yield, ranging from 0 to 4 gallons per minute). The Water Well Inventory Program database (New Hampshire Department of Environmental Services, undated) of the State of New Hampshire was queried to find candidate wells. Ten deep (deeper than $900 \mathrm{ft}$, except one that was $440 \mathrm{ft}$ in depth) bedrock wells with low water yield were selected (table 1).

All ten of the deep bedrock wells selected were logged. Two of the wells are in east-central New Hampshire, and eight are in south-central New Hampshire (fig. 1). The locations of wells were viewed in a geographic information system (GIS) along with data on bedrock formation (Lyons and others, 1997; Bennett and others, 2006) to determine the bedrock types that may occur either within or near the well, based on geologic information that is mapped at 1:250,000 scale. The actual bedrock formation within the well may vary because of heterogeneity of the rocks on a site scale. Wells drilled in igneous rocks, as determined from the State geologic map, were given the highest priority for logging because of the high potential for heat production associated with the presence of radioactive minerals (Roy and others, 1968).

\section{Geophysical Logging}

Borehole fluid temperature data were collected at 10 wells using a Mount Sopris Instrument Company 2FPA1000 (7 wells) and 2SFB-1000 (3 wells) probes, both with a resolution of $0.01^{\circ} \mathrm{C}$. Factory calibrations with reported 1-percent accuracy were used for logging in the field.

However, before logging, temperature readings from the probe were recorded in concert with a digital thermometer $\left(0.05^{\circ} \mathrm{C}\right.$ accuracy, 0.001 resolution) in warm- and cold-water baths designed to bracket the temperatures expected in the wells. Thermometer readings were later used to adjust the factorycalibrated data from the probe by applying a two-point linear correction. The median difference in temperature between the probes and the thermometer from both the warm and cold water was then used to correct the probe data. Temperature gradients were determined from temperature measurement differences at $100-\mathrm{ft}$ intervals.

In addition to temperature logs, standard borehole geophysical logs, including natural gamma and fluid conductance, were collected at selected wells, as feasible. Changes in mineralogy and bedrock type are indicated with gamma logs. Fluid conductance logs indicate groundwater flow in a borehole and can indicate where the geothermal gradient information may be masked. Temperature was logged first, going down the hole; logging rates were between 12 and $13 \mathrm{ft}$ per minute. Results from well logging are presented for each borehole investigated. Descriptions of standard boreholegeophysical logging methods and interpretation can be found in Keys (1990).

\section{Temperature and Other Borehole Logs}

Ten wells that were drilled into igneous rock in New Hampshire were logged with a temperature probe to create a temperature profile of the water column with depth (figs. 2-11). In wells with very low yield, the water temperature can be assumed to represent the bedrock temperature, which is influenced by the Earth's geothermal gradient. A two-point linear correction to the factory-calibrated data was made after data collection based on low and high temperature calibration check measurements that were made in the field. The two temperature probes used were calibrated and adjusted separately; the 2PFA-1000 probe had a low and high correction of $-1.33^{\circ} \mathrm{C}$ and $-1.45^{\circ} \mathrm{C}$; the $2 \mathrm{SFB}-1000$ probe had a low and high correction of $-1.32^{\circ} \mathrm{C}$ and $-2.35^{\circ} \mathrm{C}$.

Log depths ranged from 442 to $1,400 \mathrm{ft}$, and the average well water temperature gradients increased by 0.56 to $0.72^{\circ} \mathrm{C}$ per 100-ft depth (table 2). The coldest temperatures measured near the top of the wells were between 7.49 and $9.97^{\circ} \mathrm{C}$, and the warmest temperatures measured at the bottom of the wells ranged from 11.69 to $17.34^{\circ} \mathrm{C}$. Warm temperatures measured near the top of the water column are due to seasonal surface temperature influence and were not included in the data summary of gradient calculations.

Deflections in the temperature gradient from well B4W 571 in Brookline indicate that there may be groundwater flow between 1,100 and 1,150 ft in the well. The sharp decrease in gradient at well B4W 422 in Brookline in the bottom $50 \mathrm{ft}$ of 


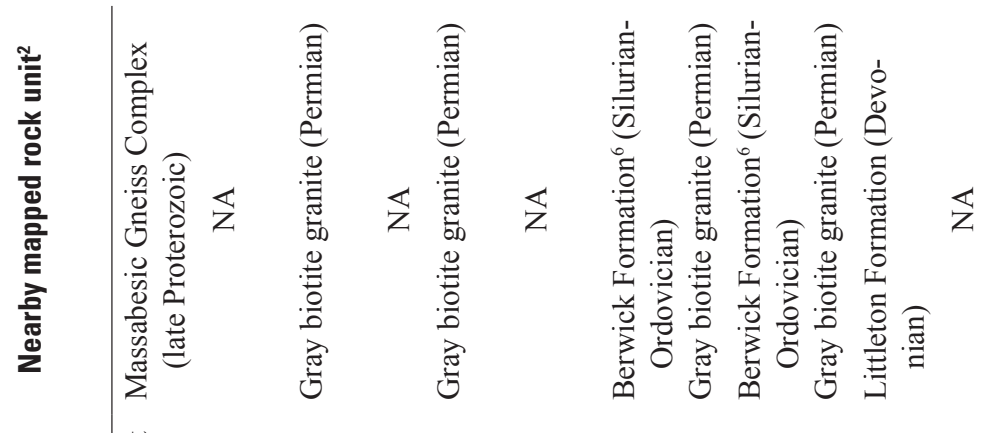

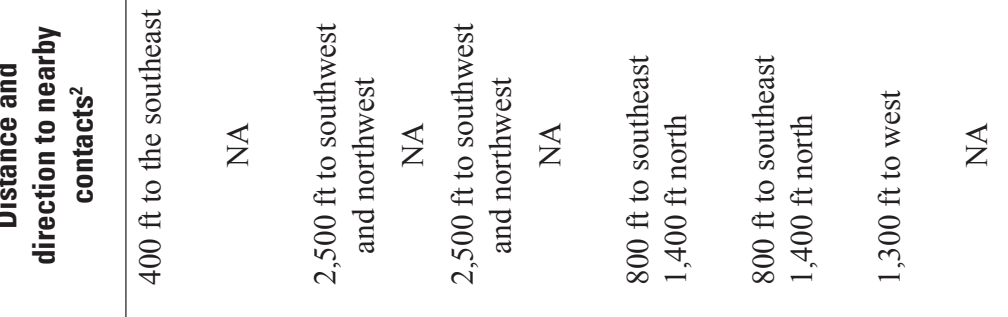

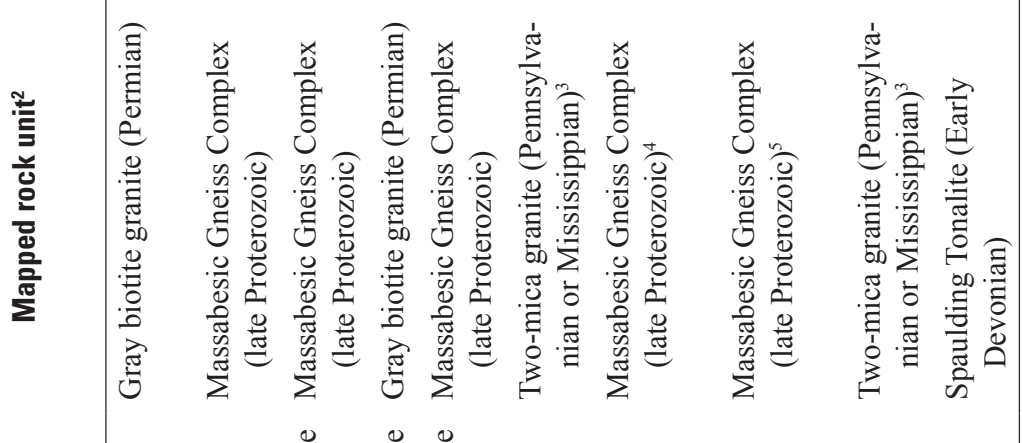

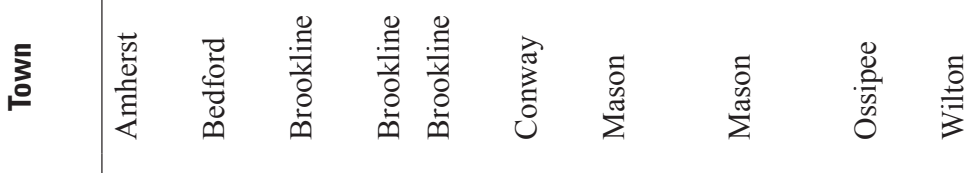

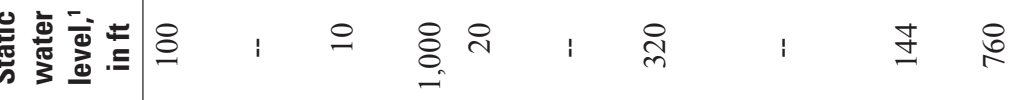

吾言

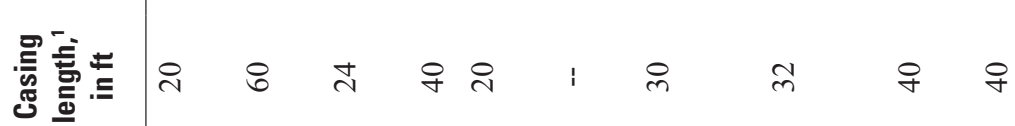

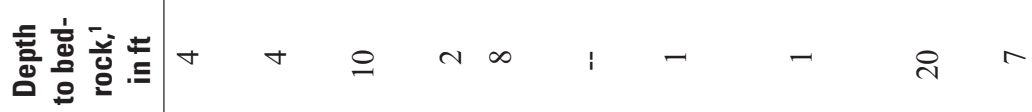

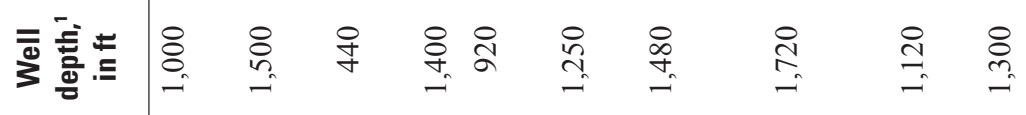

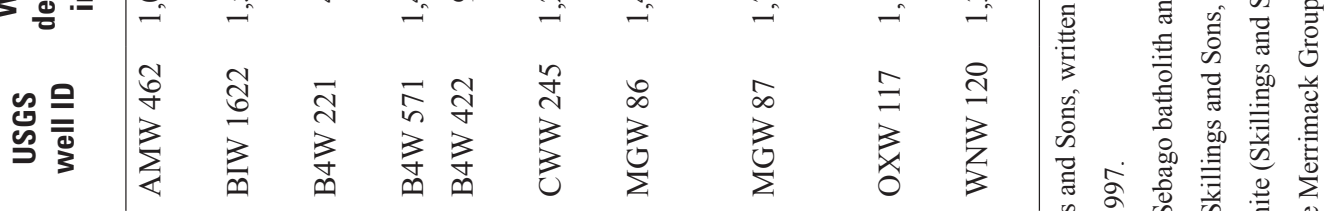

范

要

文 $巴$

.든

泀

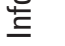

定

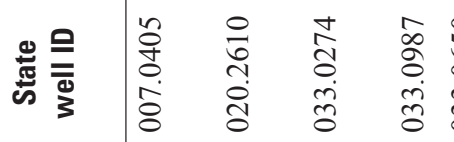

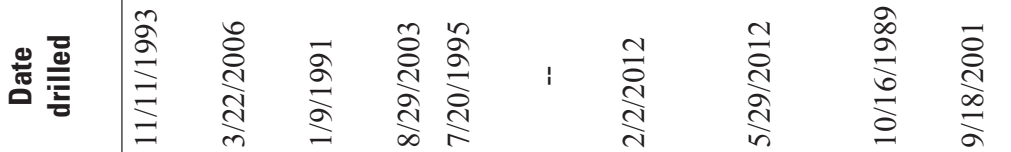

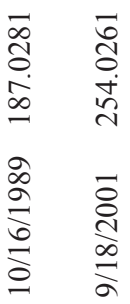

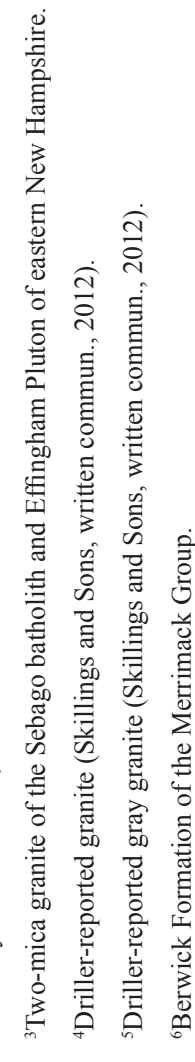




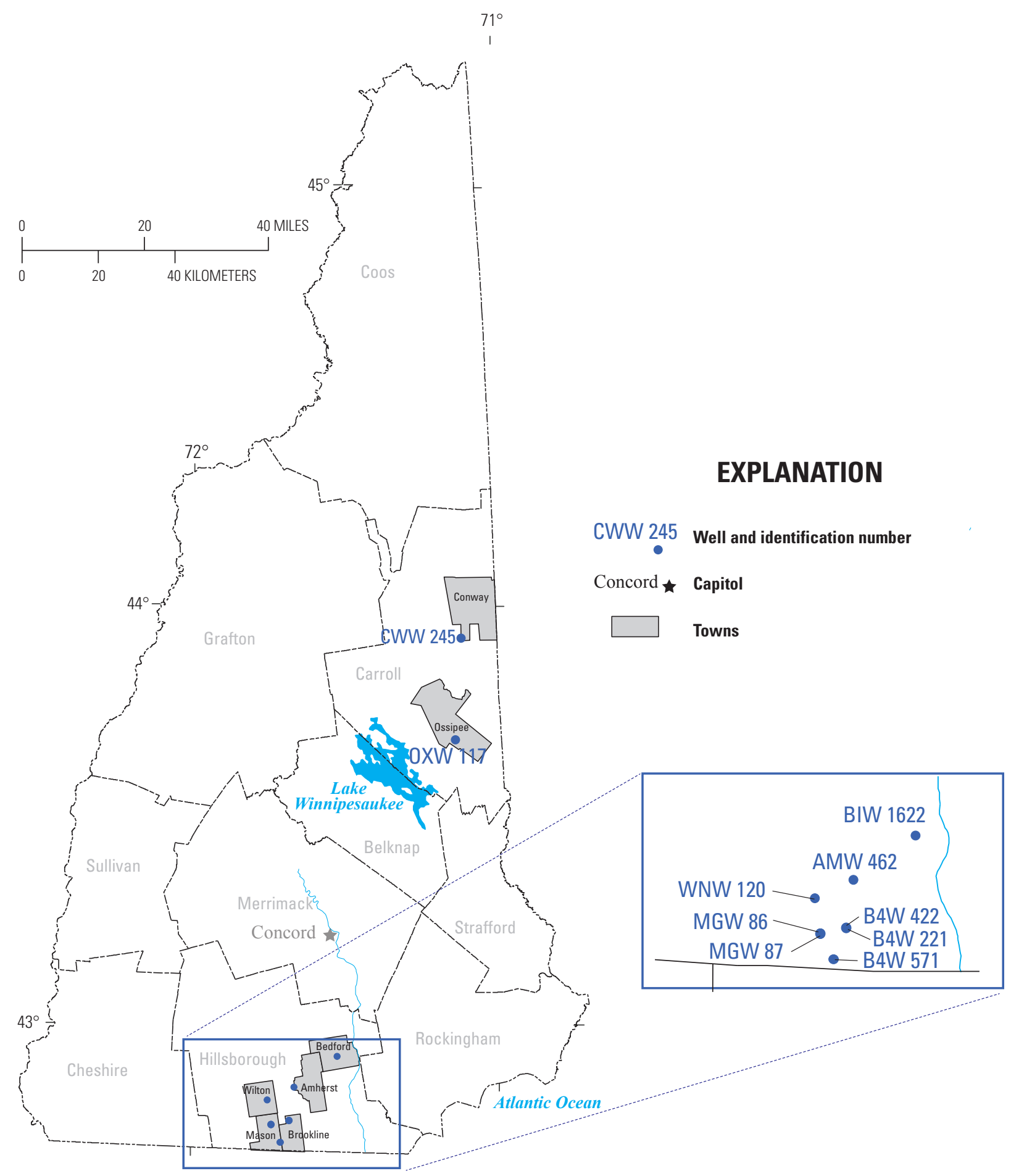

Figure 1. Locations of bedrock wells logged in New Hampshire in 2012 for geothermal gradient characterization. Well identification numbers are from the U.S. Geological Survey Groundwater Site Inventory Database of the National Water Information System (U.S. Geological Survey, 2012). 


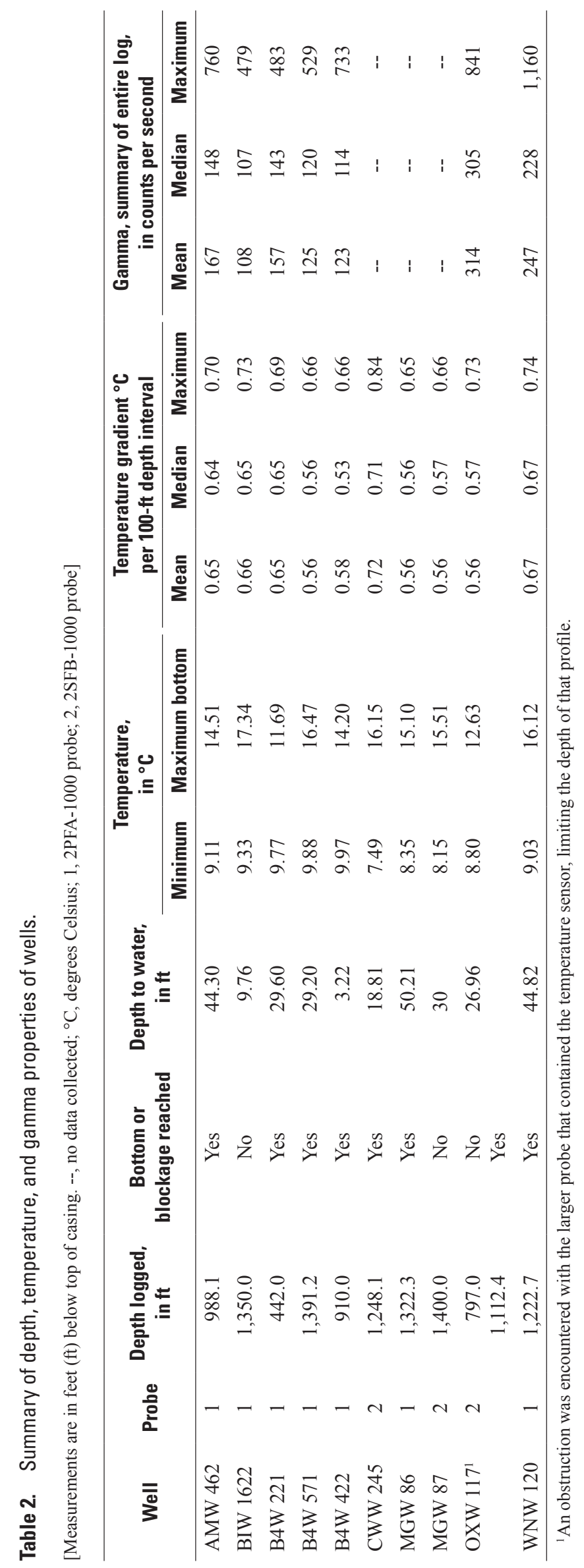


the well indicates possible groundwater inflow. The deflection in the gradient of well CWW 245 in Conway between 1,200 and $1,220 \mathrm{ft}$ indicates possible slight groundwater flow. The temperature gradient from well MGW 87 in Mason is steepest and uniform between 100 and $600 \mathrm{ft}$ of depth and decreases slightly between 600 and 1,000 ft. This decrease suggests groundwater flow and is corroborated by the fluid conductivity log. The gradient increases again below depths of $1,000 \mathrm{ft}$. This well has very similar temperature gradients to well MGW 86 in Mason and is located about $140 \mathrm{ft}$ away and slightly downslope. The conductance log from well OXW 117 in Ossipee indicates possible groundwater flow between 620 and $675 \mathrm{ft}$ of depth. Average gamma counts per second for the wells ranged from 108 to 314 .

\section{Summary}

Ten deep bedrock wells were logged during an investigation by the U.S. Geological Survey and the New Hampshire Geological Survey to characterize geothermal gradients in bedrock in New Hampshire. The well temperatures measured at the bottom of the logged intervals ranged from 11.69 to 17.34 degrees Celsius $\left({ }^{\circ} \mathrm{C}\right)$. The coldest temperatures, measured near the top of the wells ranged from 7.49 and $9.97^{\circ} \mathrm{C}$. Average geothermal gradients ranged from 0.56 to $0.72^{\circ} \mathrm{C}$ per 100 feet (ft). These gradients are in the upper half (or higher) of the range $\left(0.47\right.$ to $0.6^{\circ} \mathrm{C}$ per $\left.100 \mathrm{ft}\right)$ previously identified (Keys, 1990) for water wells in the United States and were similar to the range reported for other wells in New Hampshire (Birch and others, 1968).

Well CWW 245 in Conway had the highest average and maximum geothermal gradients, $0.72^{\circ} \mathrm{C}$ per $100 \mathrm{ft}$ and $0.84^{\circ} \mathrm{C}$ per $100 \mathrm{ft}$, respectively. Well WNW 120 in Wilton had the highest average and maximum gradients per 100-ft interval of the wells in south-central New Hampshire, 0.67 and $0.74^{\circ} \mathrm{C}$, respectively. The second highest average natural gamma radiation count (247 counts per second) also was measured at this well. The mapped bedrock unit at the two warmest wells was a two-mica granite (Pennsylvanian or Mississippian) and the Spaulding tonalite (Early Devonian), respectively (Lyons and others, 1997).

Possible groundwater flow within a well was indicated in 5 of the 10 wells logged based primarily on deviation of the temperature log; the five wells were B4W 571, B4W 422, CON01, MGW 87, and OXW 117. Fluid conductance logs were available to corroborate the temperature logs at two of the wells. Groundwater flow may slightly affect the measurement of the geothermal gradient in portions of these wells but does not obscure the overall gradient. In general, the gradients were uniform and show an increase in temperature with depth.

The two adjacent wells logged in Mason had among the lowest temperature gradients measured, with an average of $0.56^{\circ} \mathrm{C}$ per $100 \mathrm{ft}$ of depth. The bedrock is mapped as Massabesic Gneiss Complex (late Proterozoic), but it is not known if the wells penetrate contacts with the Berwick Formation (Silurian-Ordovician) or the gray biotite granite (Permian), which are mapped nearby. The driller reported the rock as gray granite, which is also the mapped unit at B4W 571 in the neighboring town of Brookline. The Brookline well also had a lower gradient than the others, with an average of $0.56^{\circ} \mathrm{C}$ per $100 \mathrm{ft}$.

Well OXW 117 in Ossipee had the highest (314) average gamma counts per second and was one of two wells that had a gradient increase deep in the well. Due to an obstruction in the well, temperature was not logged to the bottom of this well. The average temperature gradient was low $\left(0.56^{\circ} \mathrm{C}\right.$ per $\left.100 \mathrm{ft}\right)$ compared with that from the other wells. The maximum gradient was high, however, at $0.73^{\circ} \mathrm{C}$ per $100 \mathrm{ft}$. The bedrock near this well was mapped as a two-mica granite Pennsylvanian and the Littleton Formation (Devonian).

\section{References Cited}

Bennett, D.S., Wittkop, C.A., and Dicken, C.L., 2006, Bedrock geologic map of New Hampshire-A digital representation of the Lyons and others 1997 map and ancillary files: U.S. Geological Survey Data Series 215, CD-ROM, scale 1:250,000.

Billings, M.P., and Keevil, N.B., 1945, Petrography and radioactivity of four Paleozoic magma series in New Hampshire: Geological Society of America Bulletin, v. 57, no. 9, p. 797-828.

Birch, F., Roy, R.F., and Decker, E.R., 1968, Heat flow and thermal history in New York and New England, in Zen, E-an, ed., Studies of Appalachian geology—Northern and maritime: New York, New York, John Wiley and Sons, Inc., Interscience Publishers, p. 437-451.

Caruso, Louis, and Simmons, Gene, 1985, Uranium and microcracks in a 1,000-meter core, Redstone, New Hampshire: Contributions to Mineralogy and Petrology, v. 90 , no. 1, p. 1-17.

Hoag, R.B., and Stewart, G.W., 1977, Preliminary petrographic and geophysical interpretation of the exploratory geothermal drill hole and core, Redstone, New Hampshire: Durham, N.H., University of New Hampshire, 128 p.

Keys, W.S., 1990, Borehole geophysics applied to groundwater investigations: U.S. Geological Survey Techniques of Water-Resources Investigations, book 2, chap. E2, 150 p.

Lyons, J.B., Bothner, W.A., Moench, R.H., and Thompson, J.B., 1997, Bedrock geologic map of New Hampshire: U.S. Geological Survey Special Map, 2 sheets, scale 1:250,000. 
New Hampshire Department of Environmental Services, [undated], Water well inventory program: New Hampshire Department of Environmental Services, accessed September 27, 2012, at http://des.nh.gov/organization/commissioner/ gsu/wwip/index.htm.

Richardson, K.A., 1964, Thorium, uranium, and potassium in the Conway granite, New Hampshire, U.S.A., in Adams, J.A.S., and Lowder, W.M., eds., The natural radiation environment: Chicago, Ill., University of Chicago Press, p. 39-50.

Roy, R.F., Blackwell, D.D., and Birch, Francis, 1968, Heat generation of plutonic rocks and continental heat flow provinces: Earth and Planetary Science Letters, v. 5, p. 1-12.
Skinner, B.J., and Porter, S.C., 1992, The dynamic earth-An introduction to physical geology ( $2 \mathrm{~d}$ ed.): New York, John Wiley and Sons, Inc., 569 p.

U.S. Geological Survey, 2012, Site inventory for the nation: U.S. Geological Survey National Water Information System Web interface, accessed October 12, 2012, at $\mathrm{http}: / /$ waterdata.usgs.gov/nwis/inventory.

Wetterauer, R.H., and Bothner, W.A., 1977, Gravity investigation of the geothermal potential of the Conway granite, New Hampshire: EOS Transactions, v. 58, no. 6, p. 542.

Wilder, Lee, 2003, Conway granite geothermal drilling project: Granite State Geologist, no. 41, summer, p. 10-13. 
THIS PAGE INTENTIONALLY LEFT BLANK 
Figures 2-11 


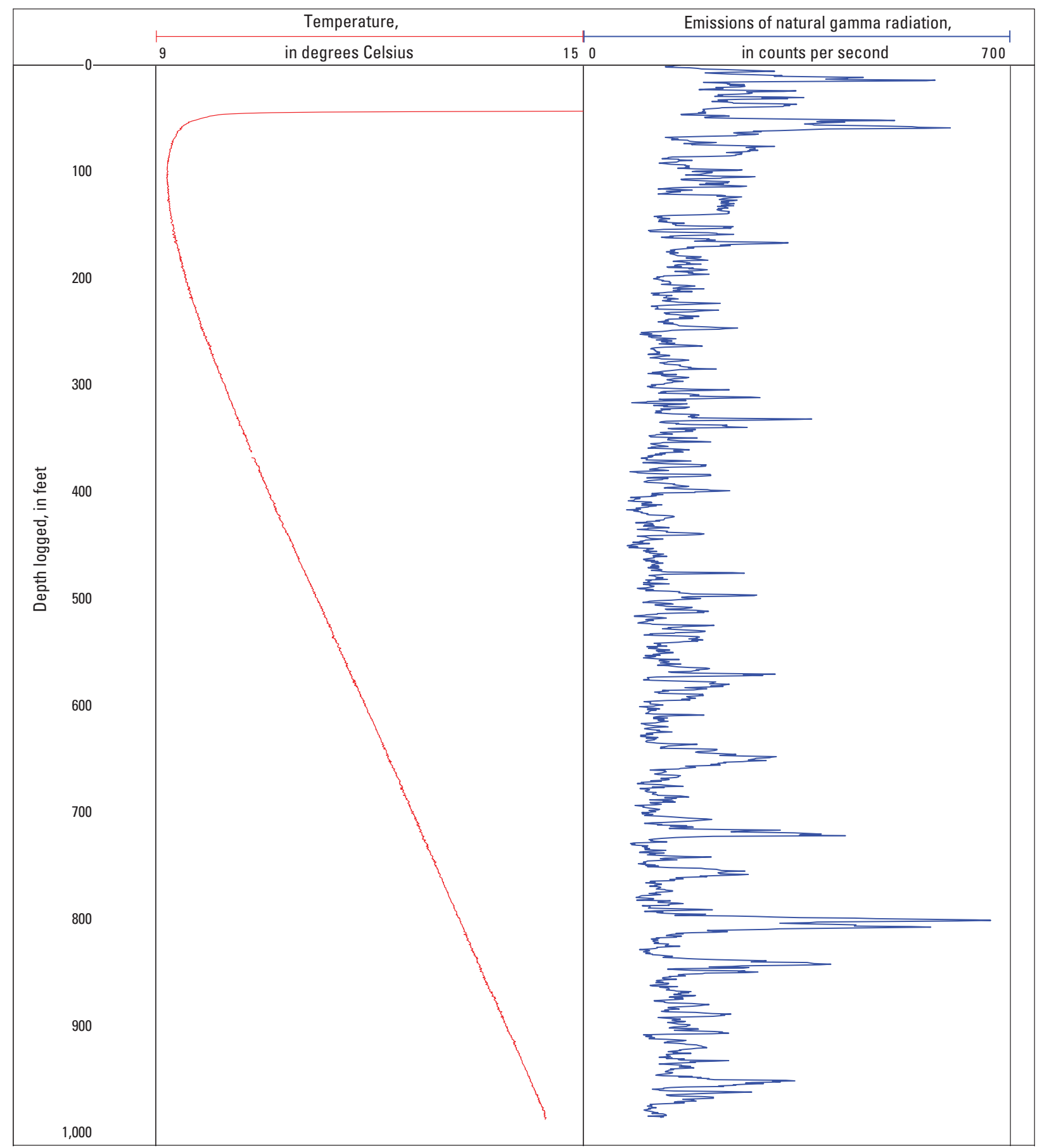

Figure 2. Temperature and gamma geophysical logs from bedrock well AMW 462 in Amherst, New Hampshire, 2012. 


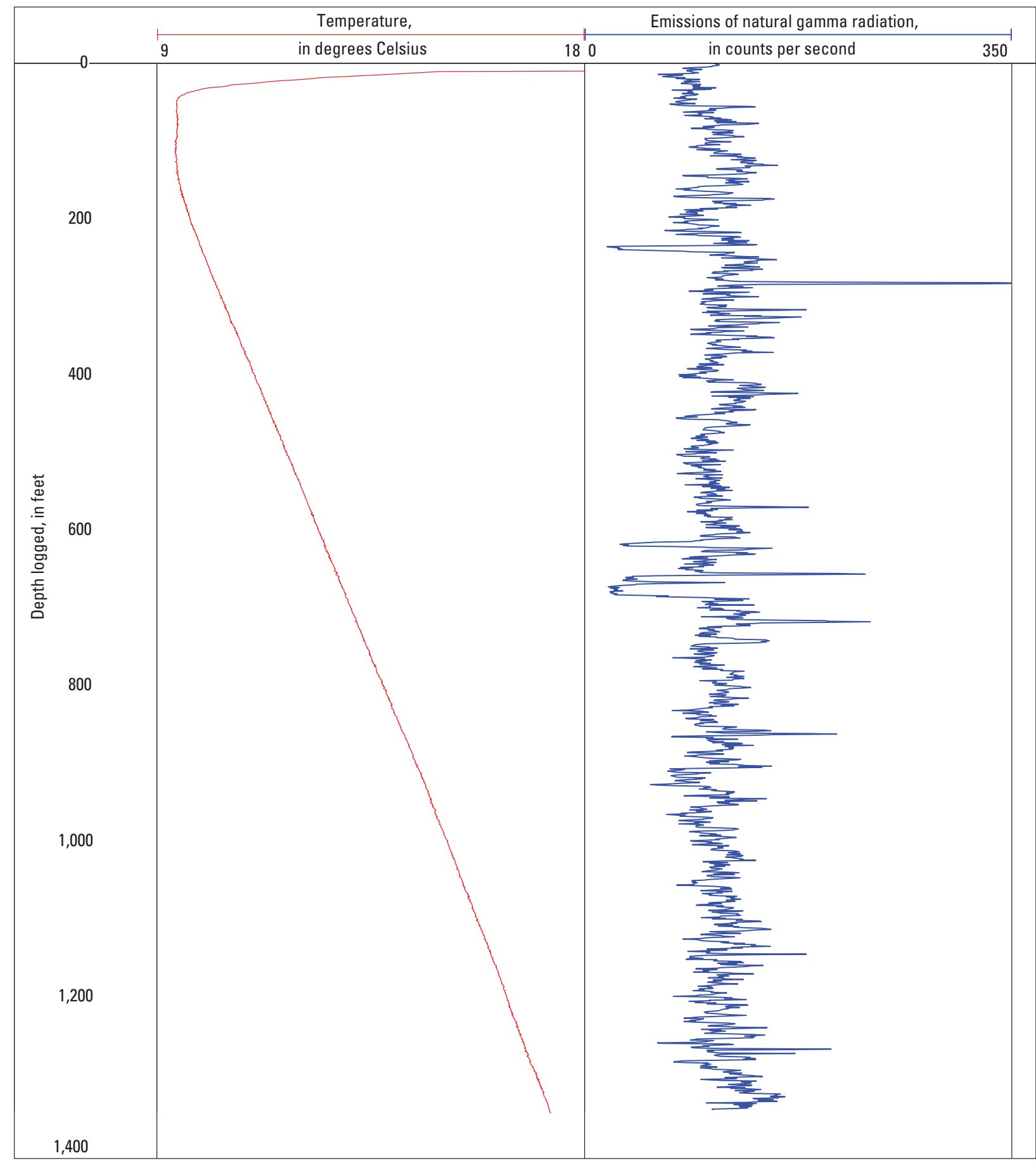

Figure 3. Temperature and gamma geophysical logs from bedrock well BIW 1622 in Bedford, New Hampshire, 2012. 


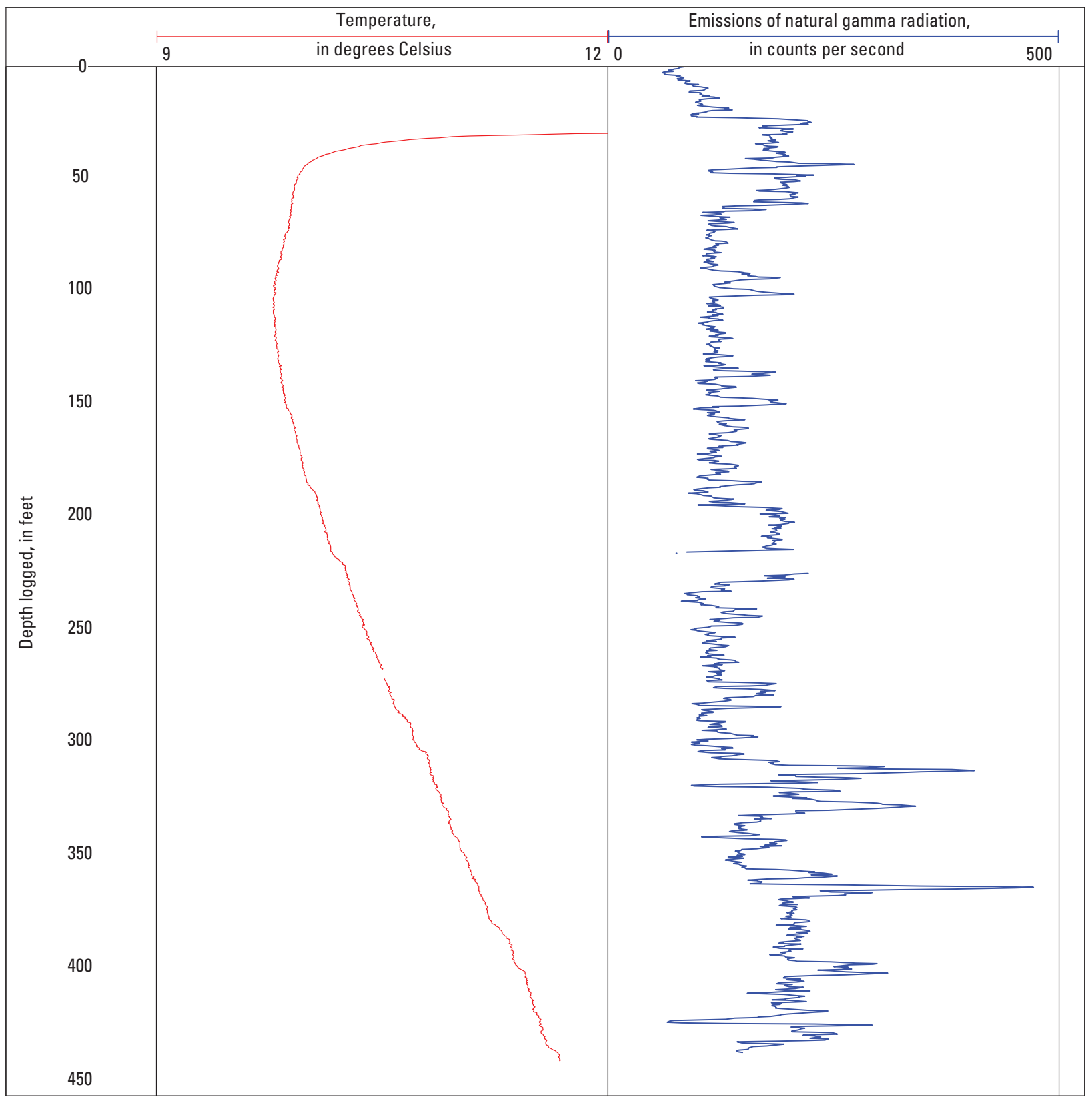

Figure 4. Temperature and gamma geophysical logs from bedrock well B4W 221 in Brookline, New Hampshire, 2012. 


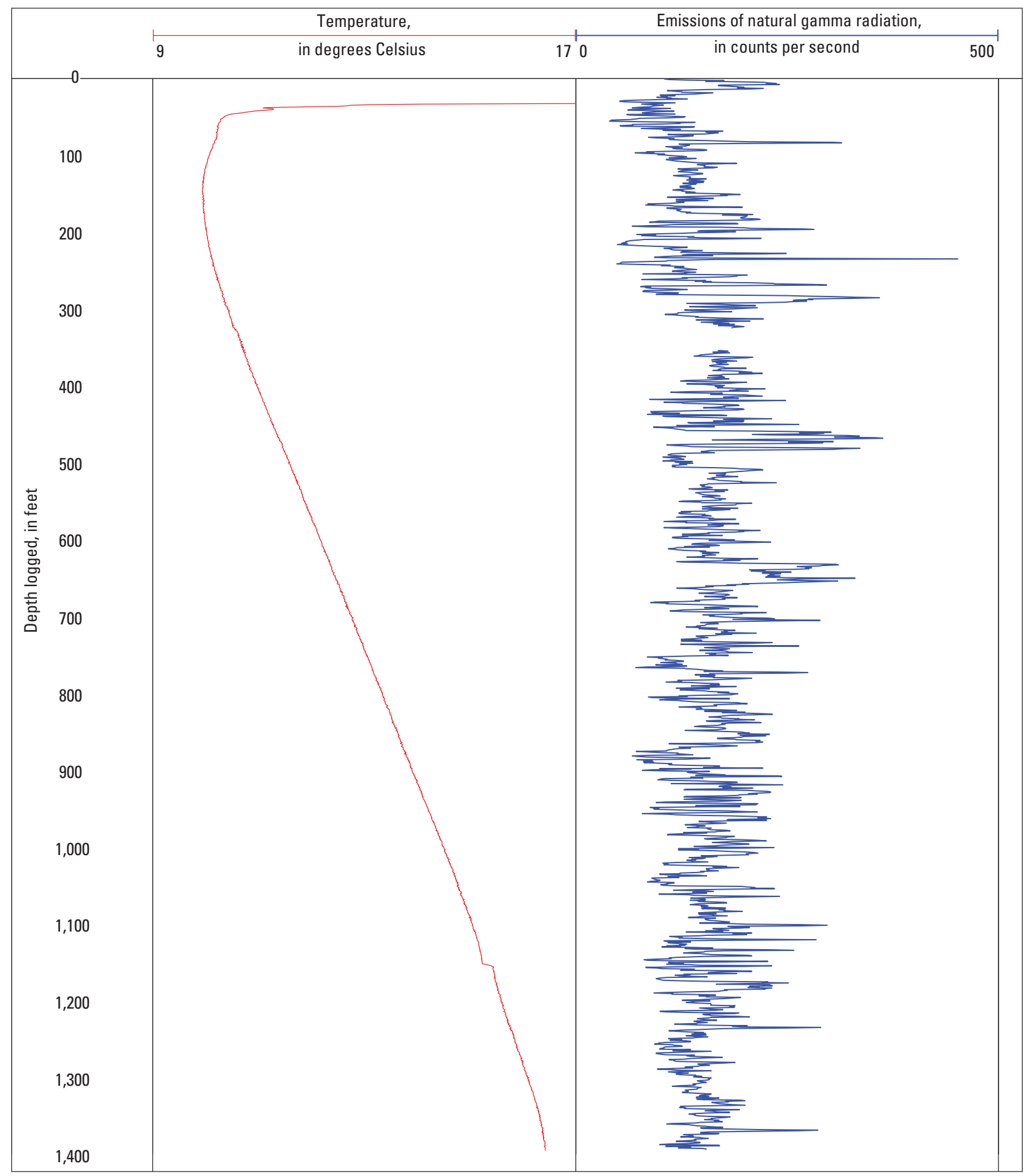

Figure 5. Temperature and gamma geophysical logs from bedrock well B4W 571 in Brookline, New Hampshire, 2012. 


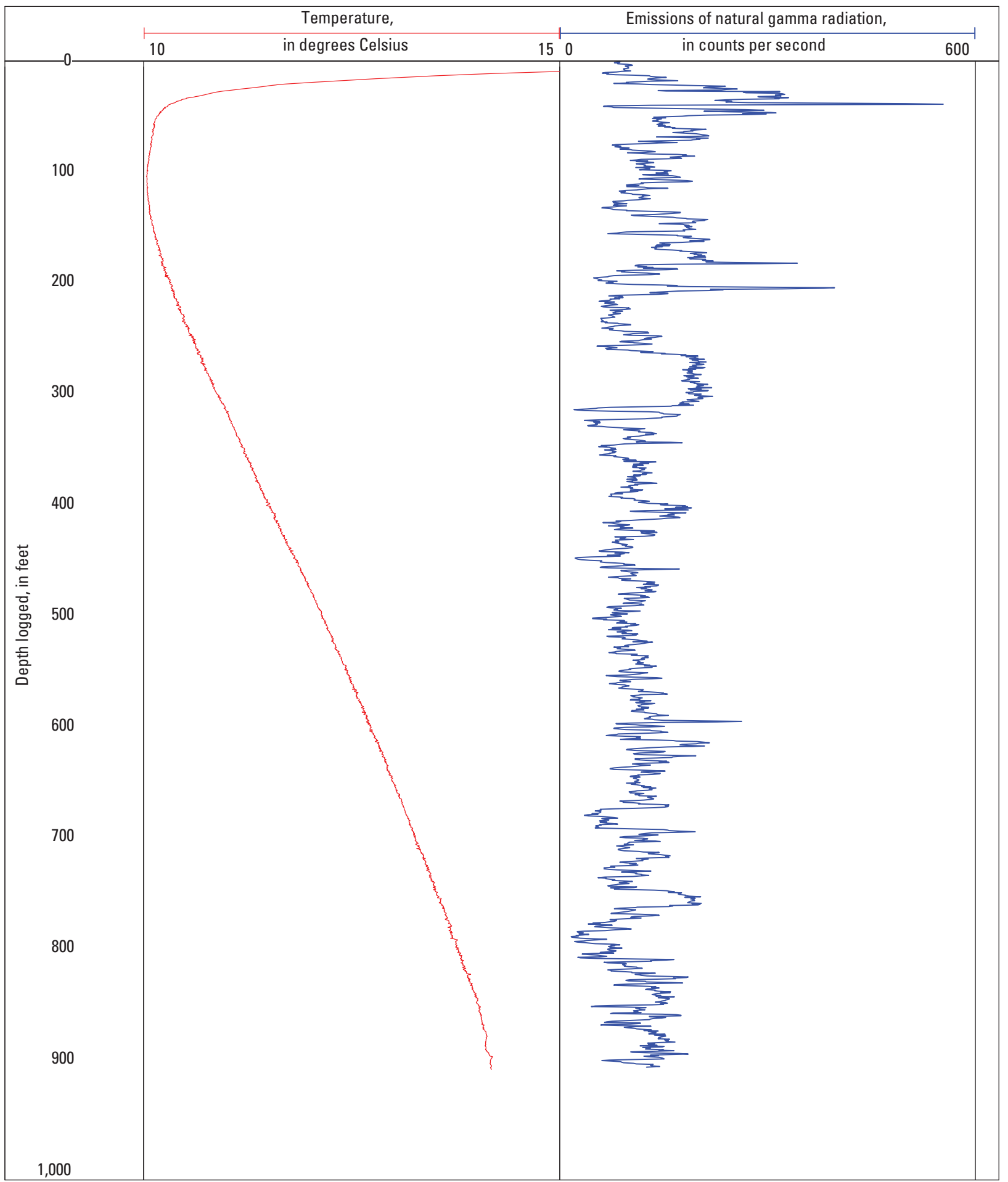

Figure 6. Temperature and gamma geophysical logs from bedrock well B4W 422 in Brookline, New Hampshire, 2012. 


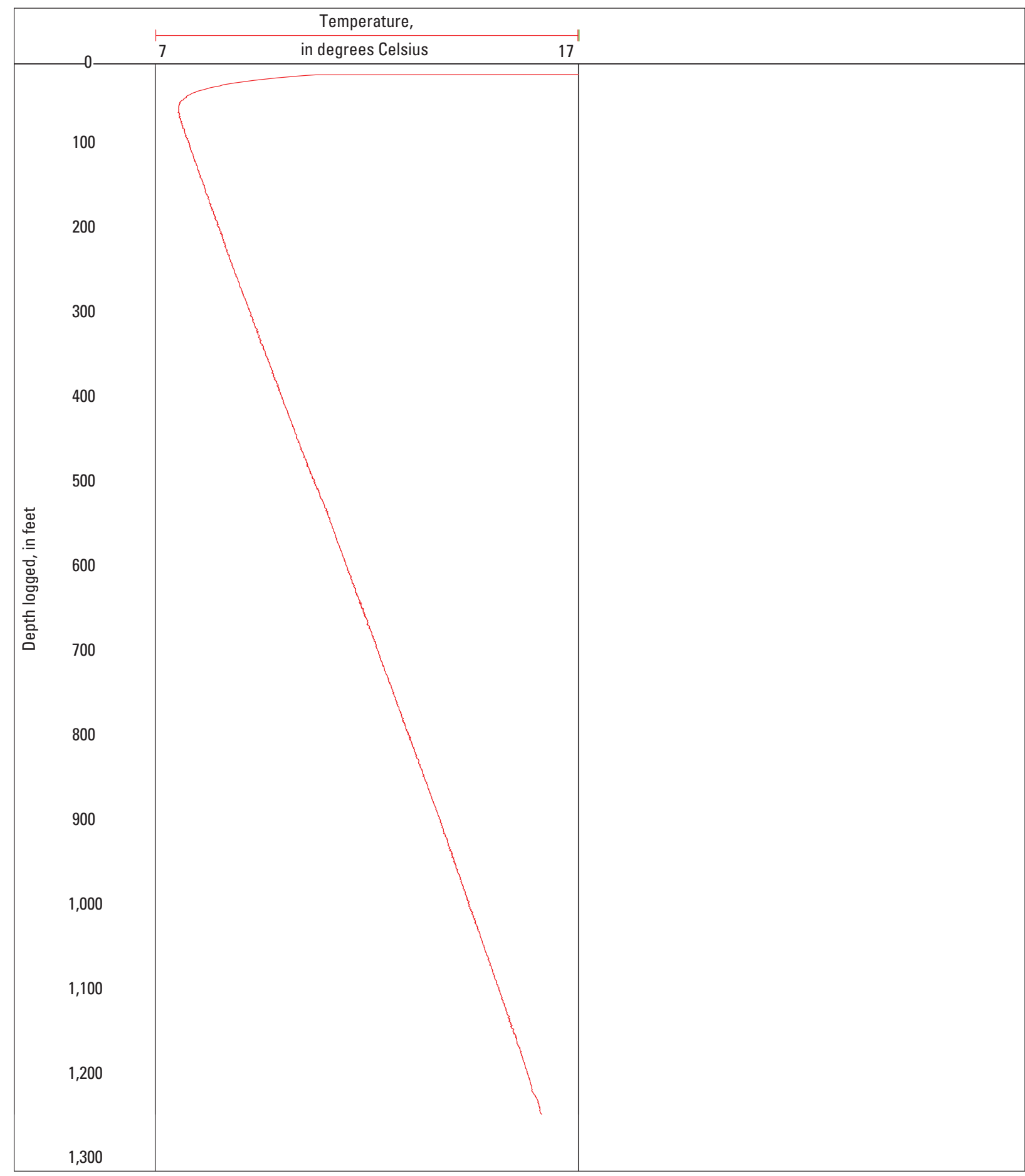

Figure 7. Temperature geophysical log from bedrock well CWW 245 in Conway, New Hampshire, 2012. 


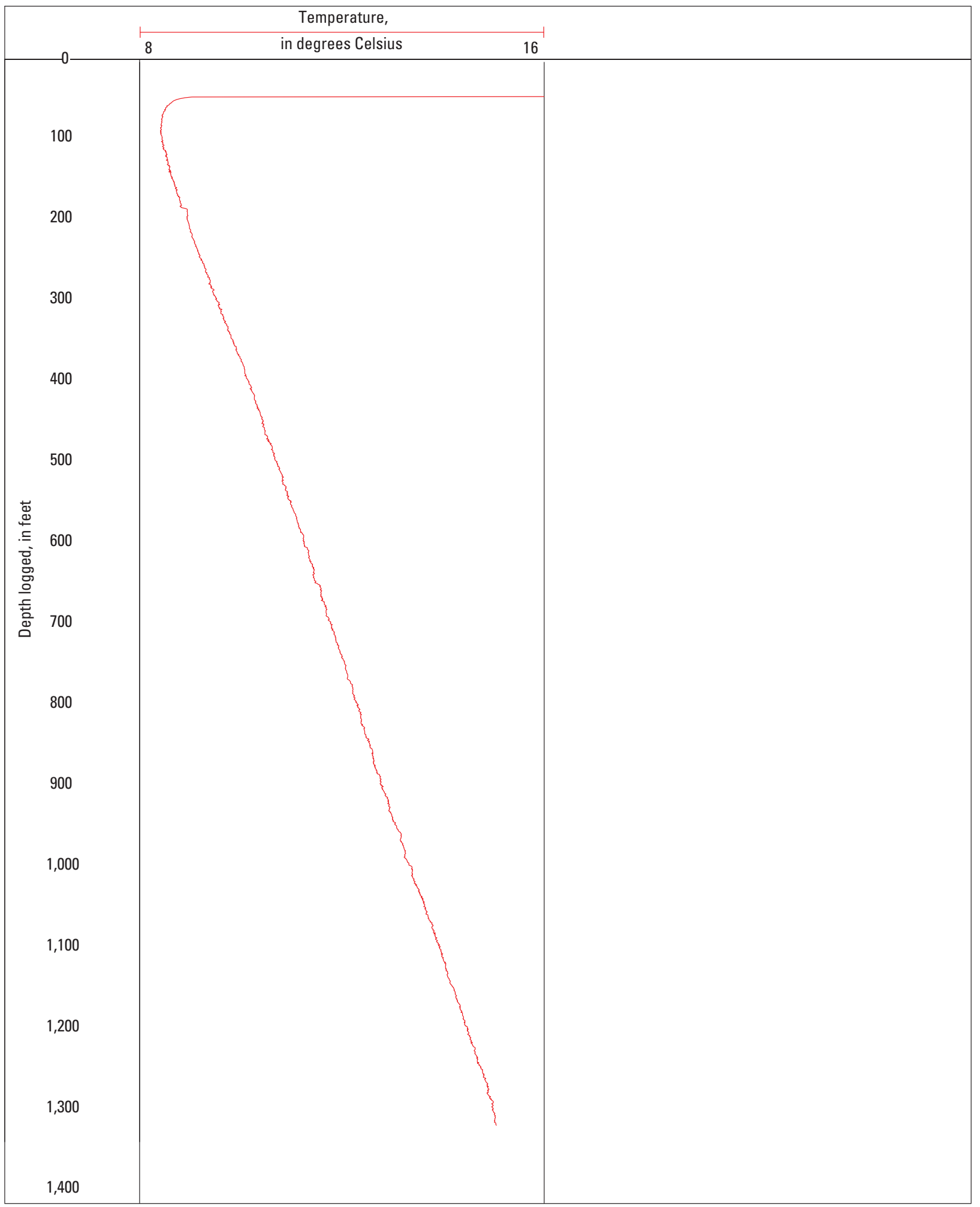

Figure 8. Temperature geophysical log from bedrock well MGW 86 in Mason, New Hampshire, 2012. 


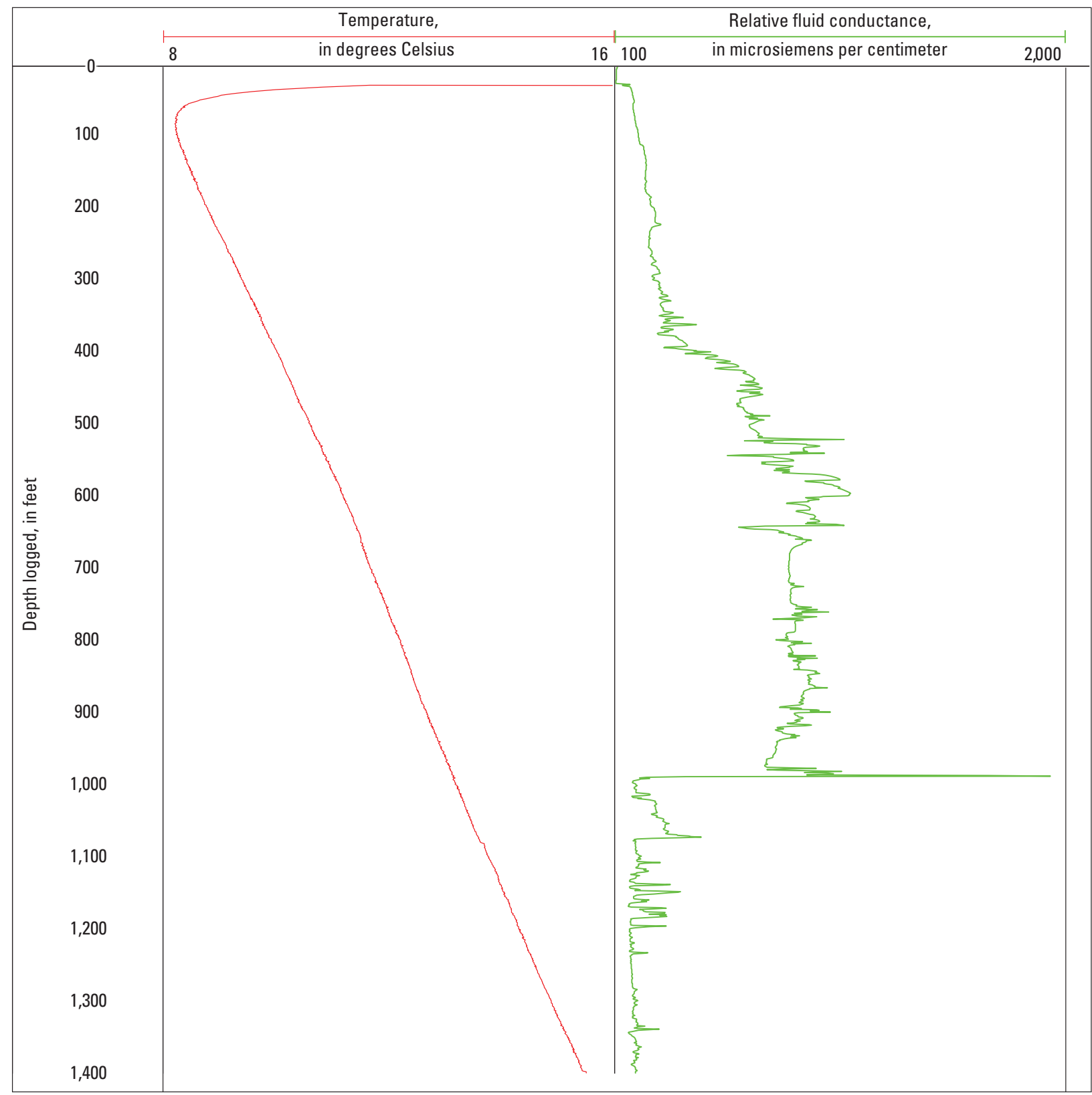

Figure 9. Temperature and conductance geophysical logs from bedrock well MGW 87 in Mason, New Hampshire, 2012. 


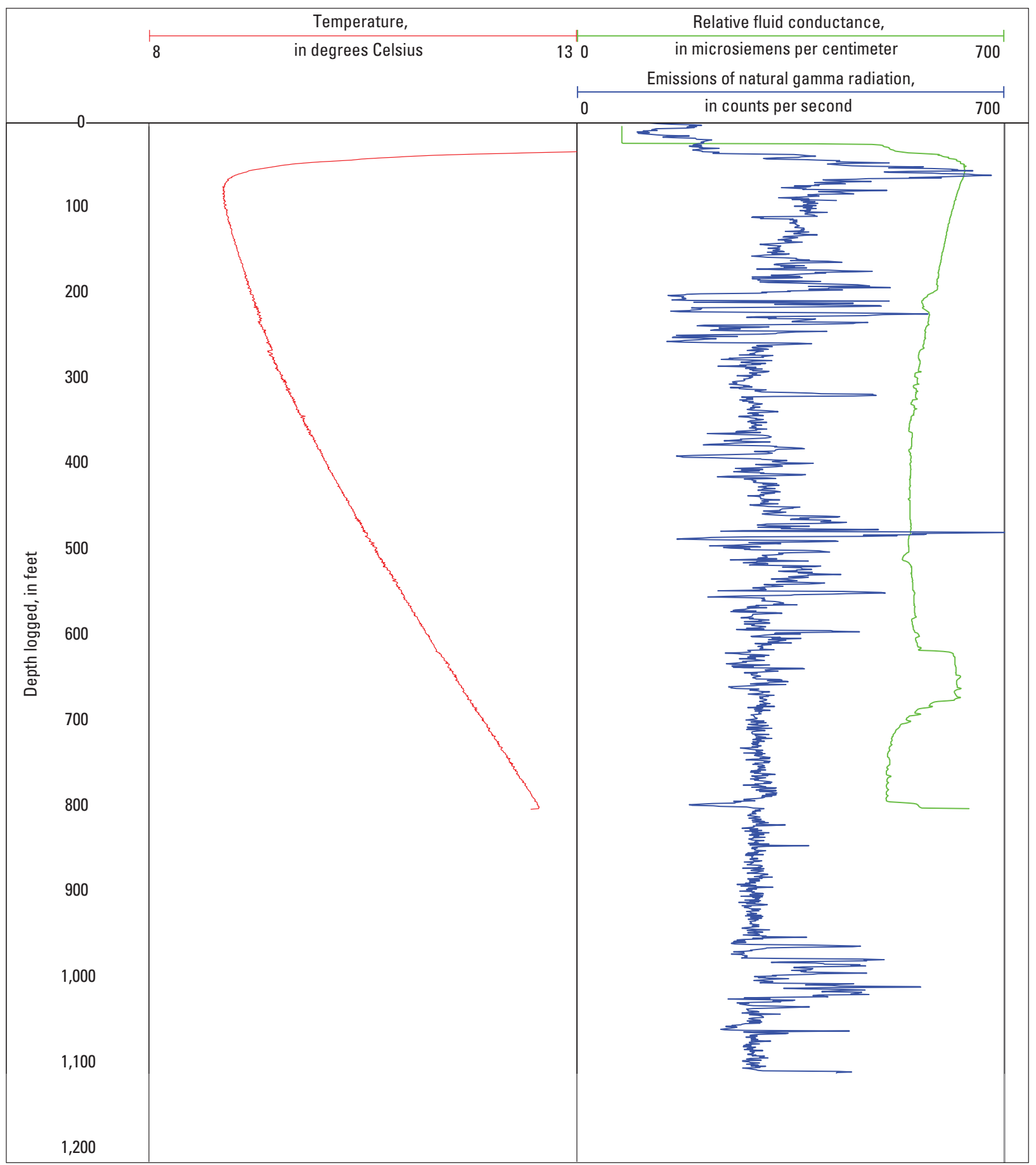

Figure 10. Temperature, conductance, and gamma geophysical logs from bedrock well OXW 117 in Ossipee, New Hampshire, 2012. 


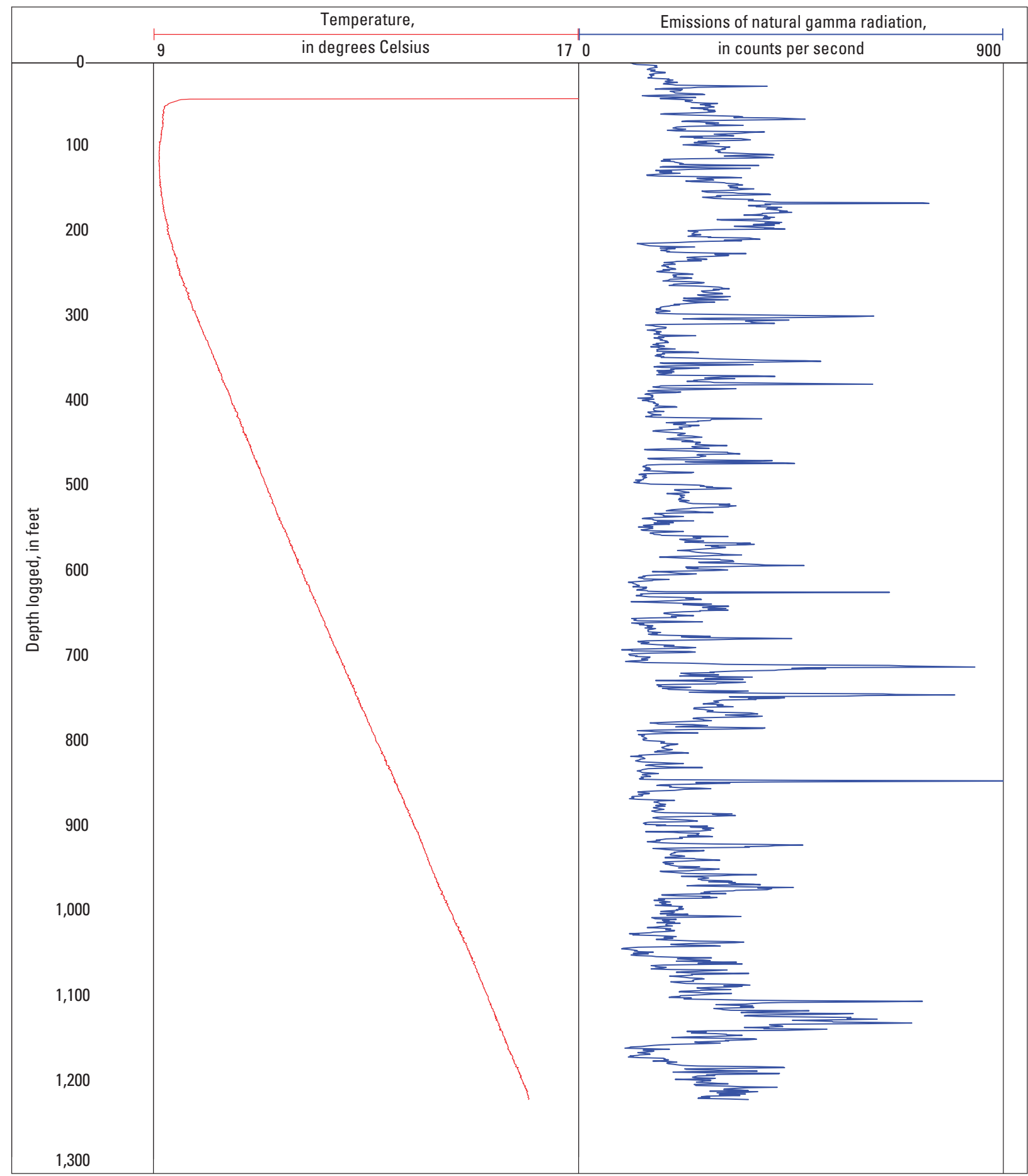

Figure 11. Temperature and gamma geophysical logs from bedrock well WNW 120 in Wilton, New Hampshire, 2012. 
THIS PAGE INTENTIONALLY LEFT BLANK 
Prepared by the Pembroke Publishing Service Center.

For more information concerning this report, contact:

Office Chief

U.S. Geological Survey

New England Water Science Center

New Hampshire-Vermont Office

331 Commerce Way, Suite 2

Pembroke, NH 03275

dc_nh@usgs.gov

or visit our Web site at:

http://nh.water.usgs.gov 
몽

몽

일

을

בิ

혹.

촐.

․․

疍

조

홍.

옹

占 